\title{
HEINONLINE
}

Citation: 46 Va. L. Rev. 4391960

Content downloaded/printed from HeinOnline (http://heinonline.org) Mon Mar 7 17:52:22 2011

-- Your use of this HeinOnline PDF indicates your acceptance of HeinOnline's Terms and Conditions of the license agreement available at http://heinonline.org/HOL/License

-- The search text of this PDF is generated from uncorrected OCR text.

-- To obtain permission to use this article beyond the scope of your HeinOnline license, please use:

https://www.copyright.com/ccc/basicSearch.do?

\&operation $=$ go\&search Type $=0$

\&lastSearch $=$ simple\&all=on\&titleOrStdNo=0042-6601 


\section{THE LIMITATION ON POLITICAL ACTIVITIES: A DISCORDANT NOTE IN THE LAW OF CHARITIES†}

\section{Elias Clark*}

7 HE twentieth century has seen the emergence of philanthropy 1 as an institution of vast wealth and of far-reaching influence on the spiritual, cultural, intellectual, and physical life of American society. The private donor has been the architect of this development. He selects, in accordance with his own estimate of the public interest, the purposes to be served, and regulates the extent and duration of that service by the flow of his wealth. For its part in the process, government has played the indulgent parent, encouraging, subsidizing but rarely interfering except to forestall the grossest excesses. Society has no cause to complain. It has been repaid incalculable dividends for the privileges granted. Nevertheless, donor autonomy sustains a system which is something less than perfect in that all funds are not put to useful service. Some are dissipated on trivial or obsolete ventures, others remain inactive, and overall there is attrition through scatteration of insufficient funds among an infinite variety of purposes. ${ }^{1}$ Could a more precise set of legal controls, assigning to government a greater responsibility in the shaping of charitable purposes, achieve a more efficient utilization of our philanthropic resources?

t The writer wishes to express his appreciation to the University of Wisconsin Law School, the Ford Foundation, and Professor Richard W. Effland of the University of $W$ isconsin for the opportunity to have participated in a seminar on charitable trusts and foundations during the summer of 1958. While the ideas expressed herein are the writer's own, he would like to express his gratitude to his colleagues in that venture for the interchange of ideas concerning the influence of law on modern charity. In addition, the writer would like to thank Mrs. Jane Stern of the New York Bar for her assistance in collecting the material for this article.

* Professor of Law, Yale University. A.B., 1943, LL.B., 1947, Yale University. Member, Connecticut and New York Bars.

1. Several states have conducted surveys as to the volume of neglected and dormant charitable funds within their respective jurisdictions. For a summary of results see Taylor, Public Accountability of Foundations and Charitable Trusts 9-49 (1953); Bogert, Proposed Legislation Regarding State Supervision of Charities, 52 Mrch. L. Rev. 633, 639-49 (1954). While these surveys were designed to expose deficiencies in existing enforcement procedures, they illustrate as well the dangers of loss which result when donors are given free rein to establish charitable purposes. 
One approach to this question is to examine an area in which a substantial measure of control has been tried. The Internal Revenue Code witholds the bountiful blessings of exemptions and tax-free contributions from any charity which engages, as a substantial part of its program, in political activities. ${ }^{2}$ This restriction is well adapted to a case study on the feasibility of legal controls. It is practically the only one which is applied without reference to whether the end result is beneficial or inimical to the interests of society. ${ }^{3}$ Its unique position stands out in bold relief when contrasted with the traditional attitudes toward using law as an instrument to control charities.

\section{The Definition of Charity as an Instrument of Control}

The definition of charity is the key to control. No one doubts that a redefinition of the conditions under which government would grant tax immunity, perpetual existence, and the machinery for enforcement could effect a dramatic change in the character of philanthropy. That the law to date has not been disposed to undertake any such responsibility is immediately apparent from an examination of existing definitions. The usual formnlation traces from the Statute of Elizabeth and includes as its basic components the rehief of poverty and the promotion of religion, education, or other public purposes. ${ }^{4}$ Alternative tests speak

2. See note 29 infra and accompanying text.

3. All of the traditional charitable purposes are justified in terms to benefit to society. There is, however, one further qualification which should perhaps be made. Both property and tax law deny charitable status to a purpose which is selfish or designed to return a profit even though that purpose might also be of some benefit to the community. 4 Scort, TRUsts $\$ 376$ (2d ed. 1956); INT. REv. Code of 1954, $501-$ (c) (3). In addition, the Code prohibits certain types of administrative activities: $\$ 502$ (feeder organizations); $\$ 503$ (prohibited transactions including loans withour adequate security or interest, excessive compensation, making services available on a preferential basis, purchasing property at a price which exceeds its value, selling property at a price under its value, and diversion of property to a private person or corporation); $\$ 504$ (unreasonable accumulations of income or diversion to noncharitable activities); and $\$ \$ 511-14$ (unrelated business income and business leases). It is submitted that these restrictions on certain administrative practices do not go to the essence of the charitable nature of the enterprise, in the same manner as the limitation on political activities.

4. The Statute of Elizabeth, 1601, 43 Eliz. 1, c. 4 (repealed). Justice Gray was the author of a more ornate formulation of these traditional categories of charity:

A charity, in the legal sense, may be more fully defined as a gift, to be applied consistently with existing laws, for the benefit of an indefinite number of persons, either by bringing their minds or hearts under the influence of education or religion, by rehieving their bodies from disease, suffering or constraint, by assisting them to establish themselves in life, or by erecting or maintaining 
with even greater generality: "anything that tends to promote welldoing and well-being of social man," "improvement and promotion of the happiness of mankind," 6 or "social interest to the community," 7 to mention but a few.

Words such as "religion," "education," and "poverty" provide a minimum opportunity for control because they include within their meanings possibilities of endless variation. ${ }^{8}$ Admittedly, each has a central core of meaning permitting general agreement as to charitable purposes which most certainly qualify. Their utility stops, however, when we try to use them as words of exclusion. Before "religion," for example, can be applied to keep out the nonreligious, there must be some agreement as to those human activities which are considered essential to religion. Two recent cases have held that congregational activities are religious even though the members of the congregation were not united in a common belief in a Supreme Being. ${ }^{9}$ These cases are not cited to criticize the result, but rather to indicate the difficulties

public buildings or works or otherwise lessening the burdens of government. Jackson v. Phillips, 96 Mass. (14 Allen) 539, 556 (1867).

This definition continues to be popular. A sampling of recent cases in which it has been invoked includes: In re Estate of Small, 244 Iowa 1209, 1220, 58 N.W.2d 277, 482 (1953) (trust upheld as charitable when the trustees were to distribute the income to persons and purposes as directed by God the Father, Jesus Christ the Son, and the Holy Spirit, and as the trustees believe would have been acceptable to the testator); People ex rel. Marsters v. Reverend Saletyni Missionaries, Inc., 409 Ill. 370, 377, 99 N.E.2d 186, 190 (1951) (seminary to educate students and conduct retreats tax exempt); State v. Union Trust Co, 227 Ind. 571, 576, 86 N.E.2d 450, 452 (1949) (trust for the publication of grandfather's diaries not charitable); Henderson v. Troy Bank \& Trust Co., 250 Ala. 456, 466, 34 So. 2d 835, 841 (1948) (financing of schools and hospital for crippled children held charitable); In re Swayze's Estate, 120 Mont. 546, 552, 191 P.2d 322, 325-26 (1948) (trust to establish a hotel as a meniorial to testatrix not charitable).

5. Ould v. Washington Hosp. for Foundlings, 95 U.S. 303, 311 (1877) (hospital for foundlings charitable); Smith v. United States Nat'l Bank, 120 Colo. 167, 180-81, 207 P.2d 1194, 1200 (1949) (public, educational, charitable, or benevolent uses held charitable); Bader Realty \& Inv. Co. v. St. Louis Housing Authority, 358 Mo. 747, 752, 217 S.W.2d 489, 492 (1949) (slum clearance held charitable).

6. Houston v. Mills Memorial Home, Inc., 202 Ga. 540, 545, 43 S.E.2d 680, 684 (1947) (old folks home held charitable).

7. Allison v. Mennonite Pablications Bd., 123 F. Supp. 23, 27 (W.D. Pa. 1954) (nonprofit corporation established to own church publication house not entitled to charitable immunity).

8. For an incisive analysis of ambiguities in legal definitions see Williams, Language and the Law-II, 61 L.Q. Rev. 179 (1945).

9. Washington Ethical Soc'y v. District of Columbia, 249 F.2d 127 (D.C. Cir. 1957); Fellowship of Humanity v. County of Alameda, 153 Cal. App. 2d 673, 315 P.2d 394 (1957). 
which courts have in moving from the abstract to the specific. In each case the one referrant which would give the religious category a degree of precision was rejected. Similar influences have shaped the other categories. Education is not confined to the classroom, ${ }^{10}$ poverty depends upon circumstances, ${ }^{11}$ and public purposes include anything useful which is not covered in the other categories. ${ }^{12}$

The test of charity was not always so flexible. In England as the concept of charity evolved, the donor's intent was sometimes subordinated to the paramount interests of the Crown. ${ }^{13}$ Even today the English law appears to exercise a tighter control than does ours. ${ }^{14}$ The trend of American law away from the parent authority has not been by accident. The courts have consciously refused to narrow the categories of charity because they recognize their own inability to delimit the

10. See, e.g., In re Los Angeles Pioneer Soc'y, 40 Cal. 2d 852, 859, 257 P.2d 1, 5 (1953) (trust for preservation and collection of historical data).

11. See, e.g., Raser v. Johnson, 9 Ill. App. 2d 375, 383, 132 N.E.2d 819, 823 (1956) (trust to pay for hospitalization and medical supplies of worthy persons who, in judgment of trustee, were unable to pay for them); Guaranty Trust Co. v. New York Community. Trust, 141 N.J. Eq. 238, 56 A.2d 907 (1948) (trust for distributing footwear to needy actors as determined by actors' association).

12. See, e.g., In re Estate of Graves, 242 Ill. 23, 28-29, 89 N.E. 672, 674 (1909) (bequest for erection of drinking fountain for horses and life-sized monument of testator's race horse a charitable gift); In the Matter of Estate of Scanlon, 230 Ill. App. 505 (1923) (trust for establishing and maintaining public bathhouse a charitable gift).

13. The principal instrument of control was the doctrine of prerogative cy pres which could be applied without reference to the donor's intent. The classic example of this doctrine is Da Costa v. De Pas, 1 Amb. 228, 27 Eng. Rep. 150 (Ch. 1754), where a Jewish testator left money in trust for the support of an assembly for reading Jewish law and instructing persons in the Jewish religion. The trust was declared void as against public policy, and the money went to a foundling home where it was used to support a Christian minister and to instruct children in the Christian religion. See Comment, $A$ Revalution of Cy Pres, 49 Yale L.J. 303 (1939).

14. Several recent English cases have witheld charitable status from purposes which seem to be clearly acceptable under American law. Oppenheim v. Tobacco Secs. Trust Co., [1951] A.C. 297 (1950) (trust for the education of children of employees of a company which employed over 110,000 persons held not charitable); Gilmour v. Coats, [1949] A.C. 426 (Roman Catholic contemplative community held not charitable). Another area for contrast is the construction given to the word "benevolent." English authority continues to treat it as broader than charitable, see Chichester Diocesan Fund v. Simpson, [1944] A.C. 341 (trust for charitable or benevolent objects in England held void for uncertainty), while most American authority construes the word as synonymous with "charitable." 4 Scotr, TRusts $\$ 398.1$ (2d ed. 1956). For a discussion of the English definition of charity see Brunyate, The Legal Definition of Charity, 61 L.Q. Rev. 268 (1945). In 1952 a commission recommended that the definition of charity be modernized to allow flexibility of interpretation but that the existing case law on the subject be preserved. Committee on Law and Practice, Report Relating to Charitable Trusts, CMD. No. 8710, 31-36 (1952) (Nathan Report). 
ways in which society might be served. Charity is in constant flux, varying with the place and times. The dangers perceived in judicial definitions of charity are that the prejudices of today will inhibit the growth and change necessary to meet the demands of future generations. So it is that the donor is given free rein to chart the course of charitable objectives. Courts, while frequently suggesting that the funds might well have been put to better use, accept as charitable those generally beneficial purposes which are not affirmatively absurd, obscene, illegal, excessively selfish, or specifically offensive to some considerable segment of the population. ${ }^{15}$

For the most part the issue comes up within a context in which society's interest appears minimal. A donor has died, and the court must choose between approving a questionable purpose or awarding the property to heirs whom the testator had pro tanto disinherited. The judge's decision is obvious. He believes that the concept of private property entitles the owner to dictate the future disposition of that property, he wants to encourage charity, and he knows that if he errs on the side of leniency, cy pres may be invoked at a later date in favor of a more practical use of the property.

The responsibility of the decision-maker is more complex when the issue involves tax privileges. The community has a stake in enterprises which are to receive governmental subsidy. And if control is the objective, the manipulation of exemptions can effect an immediate influence on the channelling of private funds into high priority areas. ${ }^{16}$ The federal courts recognize an authority in the tax field independent of

15. This writer has used this description of the process on a previous occasion. While it contains its share of ambiguities, it has the advantage of indicating that the initial presumption is one of validity. Clark, Charitable Trusts, the Fourteentb Amendment and the Will of Stephen Girard, 66 Y $\mathrm{ALE}$ L.J. 979, 998 n.72 (1957). A more complete statement requires a listing of ad boc responses to particular situations. As Professor Scott has said: "The truth of the matter is that it is impossible to frame a perfect definition of charitable purposes. There is no fixed standard to determine what purposes are charitable," 4 Scorr, Trusts $\$ 368$, at 2629 (2d ed. 1956). Cf. Reiling, Federal Taxation: What Is a Charitable Organization?, 44 A.B.A.J. 525 (1958). Statements frequently appear in the cases to the effect that the judge's personal appraisal of the wisdom or utility of the trust is irrelevant. See Zolmidans, Americais LAW OF ChaRITIES 148-49 (1924).

16. The Code presently encourages gifts to certain high priority charities. The charitable deduction is limited to $20 \%$ of adjusted gross income. If, however, at least $10 \%$ of such income is given to a church, educational institution, or hospital, then the outer limit of the total deduction is increased to $30 \%$ of adjusted gross income. INr. Rev. CoDe of 1954, $\$ 170$ (b) (1) (B). 
local law characterizations, ${ }^{17}$ but this authority is rarely invoked. The statutory definitions of charity are broad, and federal judges have no more desire to act as censors than their state court colleagues.

Property and tax law are in harmony except in one important particular. The former permits political activities in pursuit of charitable objectives, ${ }^{18}$ while the latter makes such activities the basis for denying charitable tax privileges. Implicit in these results is a fundamental difference in attitude toward the regulation of charities. The limitation on political activities affects any charity which must, through the force of circumstances, resort to governmental assistance to achieve its ends. No inquiry is permitted into benefits which may thereby be bestowed. The one exception, based upon the substantiality of the activity, permits a quantitative rather than a qualitative discrimination. The general law of charity, in effect, presumes a purpose to be charitable unless affirmatively shown to be inimical to the interests of society. The political activities rule not only reverses this inference, but also goes a step beyond by making a showing of substantial activity conclusive grounds for refusing charitable status.

\section{The Development of the Limitation on Political Activity}

The income tax of 1894 included an exemption for any corporation or association organized exclusively for religious, educational, or charitable purposes. ${ }^{19}$ While this statute was later written off as unconstitutional, ${ }^{20}$ many of its provisions survived as prototypes for subsequent legislation. Specifically, the exemption was repeated in the $1913 \mathrm{act}^{21}$ and from that point became a permanent fixture in the tax law. In 1917 the correlative provision permitting the taxpayer to deduct a

17. Cases in which local law was held not to be determinative of taxability include: Sharpe's Estate v. Commissioner, 148 F.2d 179 (3d Cir. 1945); Federal Reserve Bank v. Omaha Nat'l Bank, 45 F.2d 511 (8th Cir. 1930), cert. denied, 282 U.S. 902 (1931); Eagan v. Commissioner, 43 F.2d 881 (5th Cir. 1930), reversing 17 B.T.A. 694 (1929); Greiss v. United States, 146 F. Supp. 505 (N.D. Ill. 1956). On the other hand, cases in which local law has influenced taxability include: Schoellkopf $v$. United States, 124 F.2d 982 (2d Cir. 1942); Howell v. Dudley, 154 F. Supp. 571 (W.D. Pa. 1957); Estate of Carolyn E. Gray, 2 T.C. 97 (1943); Estate of Agnes C. Robinson, 1 T.C. 19 (1942), acq., 1943 Cun. BuLI. 19.

18. See authorities cited note 44 infra.

19. 28 Stat. 556 (1894). For a discussion of the early history of federal tax exemptions see Reiling, Federal Taxation: What ls a Charitable Organization?, 44 A.B.A.J. 525 (1958).

20. Pollock v. Farmers' Loan \& Trust Co., 158 U.S. 601 (1895).

21. 38 Stat. 172 (1913) (now INT. Rev. CoDE or 1954, $\$ 501$ ). 
contribution from his personal income tax was enacted, ${ }^{22}$ again with the qualification that the recipient be exclusively organized for religious, educational, or charitable purposes. A similar deduction was added to the estate $\operatorname{tax}^{23}$ in $1926^{24}$ and to the gift tax which, after an interim period of validity from 1924 to $1926,{ }^{25}$ became a permanent part of the tax law in $1932 .{ }^{26}$ Prior to 1934 none of these statutes made direct reference to political activity. It was, however, recognized both in the regulations and decisions that such activity was grounds for denying the exemption. ${ }^{27}$ Authority on the point was sufficiently settled so that in 1934 when the prohibition was put into the statute, ${ }^{28}$ there was no discernible change in the flow of decisions.

The statutory language as it appears today in section 501 (c)(3) qualifies a charitable corporation, chest, fund, or foundation for exemption from corporate taxes if "no substantial part of the activities of which is carrying on propaganda, or otherwise attempting, to influence legislation, and which does not participate in, or intervene in (including the publishing or distributing of statements), any political campaign on behalf of any candidate for public office." Similar language, except for omission of the clause about political campaigns and candidates, appears in section 170 , setting out the deductibility of charitable gifts, and in comparable sections of the estate and gift taxes. ${ }^{29}$

From the practical point of view, charities are not very much concerned about their own taxes. They may, under existing law, organize as civic associations, engage in political activities, and retain their exemption from corporate taxes. ${ }^{30}$ It is, however, vital that they qualify

22. 40 Stat. 330 (1917) (now INT. Rev. Code of 1954, \$ 170).

23. 39 Stat. 777 (1916).

24. 44 Stat. 835 (1926) (now INr. Rev. Code of 1954, $\$ 2055$ (a)).

25. 43 Stat. 313,314 (1924).

26. 47 Stat. 245, 247-48 (1932) (now INT. Rev. Cone of 1954, \$ 2522).

27. See notes 32-37 infra and accompanying text.

28. 48 Stat. $690,700,755,760$ (1934) (income tax, exempt corporations, estate tax, and gift tax, respectively).

29. The clause concerning participation in political campaigns was added to the Revenue Bill of 1954 by way of amendment introduced on the Senate floor by Senator Johnson. No explanation was given for this addition. 100 CoNG. REC. 9604 (1954). In addition to $\$ 170$ and 501 (c) (3) of the income tax, the restriction on political activities also appears in $\$ 2055$ (a) (3) (estate tax deduction) and $\$ 2522$ (a) (2) (gift tax deduction). A number of states impose a similar limitation on contributions made by individuals. See, e.g., CaI. Rev. \& TAx. Code $\S 17214(\mathrm{~b}) ;$ N.Y. Tax Laws $\S 360(10)(b)$.

30. INr. Rev. Code of 1954, $\$ 501$ (c) (4). See Debs Memorial Radio Fund, Inc. v. 
as exempt charities in order that donors may deduct contributions made to them..$^{31}$

It is not clear from the early history of the restriction on political activities whether it evolved as a result of carefully considered policy, or of the Treasury's understandable desire to place outer limits around any exemption, or on the assumption that established property law required it. The principle first appeared in the regulations of 1919 and was primarily aimed at "controversial" political activity. ${ }^{32}$ During the twenties it was successfully applied in several minor cases before the Board of Tax Appeals. ${ }^{33}$ In 1930 it moved center stage. The case was Slee $v$. Commissioner, ${ }^{3 \pm}$ involving the deductibility of gifts to the American Birth Control League. Judge Learned Hand, writing for a unanimous court, held that the clinical activities of the League were charitable. The Board of Tax Appeals had held, however, that the League's agitation for repeal of birth control laws put the League outside charitable status. ${ }^{35}$ Judge Hand agreed. He placed little emphasis on the controversial nature of the issue, suggesting that the political aims of the League might be both right and commendable. The deduction must, nevertheless, be disallowed because:

Political agitation as such is outside the statute, however innocent the aim, though it adds nothing to dub it "propaganda," a polemical word used to decry the publicity of the other side. Controversies of that sort must be conducted without public subvention; the Treasury stands aside from them. ${ }^{36}$

The decision in the Slee case has served as the cornerstone for all that has followed. Later courts have accepted the principle as settled,

Commissioner, 148 F.2d 948 (2d Cir. 1945) (association organized to conduct a free public radio forum for dissemination of liberal and progressive social views is exempt).

31. For the applicable deduction provisions see INT. Rev. CoDE of 1954, §170(c) (2)(D) (income tax); $\$ 2055$ (a) (2)-(3) (estate tax); $\$ 2522$ (a) (2) (gift tax).

32. "But associations formed to disseminate controversial or partisan propaganda are not educational within the meaning of the statute." Treas. Reg. 45, art. 517 (1919), in T.D. 2831, 21 TrEas. Decs. INT. Rev. 285 (1920).

33. See, e.g., Herbert E. Fales, 9 B.T.A. 828 (1927) (evidence indicated that Scientific Temperance Fed'n, Massachusetts Anti-Saloon League, Massachusetts Anti-Cigarette League, and International Reform Bureau were formed to disseminate controversial propaganda); Sophia G. Coxe, 5 B.T.A. 261 (1926), acq., VI-1 Cum. Bull. 2 (1927) (League to Enforce Peace not exclusively charitable).

34. 42 F.2d 184 (2d Cir. 1930), 72 A.L.R. 400 (1931).

35. J. Noah H. Slee, 15 B.T.A. 710 (1929).

36. Slee v. Commissioner, 42 F.2d 184, 185 (2d Cir. 1930). 
and have seldom inquired as to whether it is well-founded in policy. ${ }^{37}$ In retrospect it may be suggested that this deference is due more to the decision's primacy in the field, as well as the eloquence and illustrious name of its author, than to the cogency of its argument. The decision actually assumes the validity of the restriction without attempting to justify it by argument or authority.

Shortly thereafter, in 1934, the restriction became part of the statute. ${ }^{38}$ In view of the existing case law on the subject, it is not clear what the proponents of the legislation sought to accomplish. One view holds that the statute was designed to liberalize the case law. ${ }^{39}$ The theory that the legislation was narrowly conceived finds support in the debates. It appears that the proponents wanted to restrict political agitation, selfishly motivated, to secure some personal interests of the donor. ${ }^{40}$ No mention is made of political activities being inherently improper. The all inclusive proscription resulted, as the debates malke clear, not from broad policy considerations, but from the draftsmen's inability to frame a more selective formula. ${ }^{41}$

One explanation for the ready acceptance of the limitation during this formative period may perhaps be found in an erroneous assumption that the general law of charities required such a result. This view would have found support in two prominent Massachusetts decisions. In the first, Jackson v. Pbillips, ${ }^{42}$ decided in 1867 , the court lield that a trust to promote "women's rights" was not charitable. Justice Gray, equating women's rights with the suffragette movement, stated that the court's duty was to expound the laws as they stand and not to assist in "the overthrowing or changing of them" by accepting a political purpose as charitable. The second decision, coming fifty-five years later and

37. See, e.g., Sharpe's Estate v. Commissioner, 148 F.2d 179 (3d Cir. 1945); Marshall v. Commissioner, 147 F.2d 75 (2d Cir.), cert. denied, 325 U.S. 872 (1945).

38. See note 28 supra.

39. "They [the courts] have also applied the principle, that the section being remedial must be liberally construed." Seasongood v. Commissioner, 227 F.2d 907, 910 (6th Cir. 1955).

40. Senator Reed said of the bill: "There is no reason in the world why a contribution made to the National Economy League should be deductible as if it were a charitable contribution if it is a selfish one made to advance the interests of the giver of the money. That is what the committee was trying to reach . ..." 78 Cong. REc. 5861 (1934).

41. Senator Reed's remarks continue: "[W]e found great difficulty in phrasing the amendment. I do not reproach the draftsmen. I think we gave them an impossible task; but this amendment goes further than the committee intended to go." Ibid.

42. 96 Mass. (14 Allen) 539 (1867). 
involving an identical disposition, found the court no more prepared than its predecessor to give the women their due. ${ }^{43}$ On the earlier authority the purpose was held noncharitable. By way of demonstrating the prejudices of the place and times, the first case also involved a trust for the abolition of Negro slavery, and the second a trust for the promotion of temperance; neither court had any difficulty in finding these trusts nonpolitical.

The courts of other jurisdictions have refused to be persuaded by Justice Gray's opinion, and the commentators now suggest that the Massachusetts approach is pretty much of a dead letter. ${ }^{44}$ The reasoning of these decisions is in dramatic contrast to the tax cases. In language varying to fit the specific facts of the case, each makes the point that an appeal to political institutions to improve the lot of mankind is entirely consistent with a broad and dynamic conception of charity.

By the time a few of the tax cases began to take note of this line of authority, it was too late to effect a change. The Slee decision and the 1934 legislation foreclosed debate, leaving to subsequent decisions only

43. Bowditch v. Attorney Gen., 241 Mass. 168, 134 N.E. 796 (1922), 28 A.L.R. 713 (1924).

44. "The trend of modern authority has been toward the upholding of trusts which have for their object the creation of a more enlightened public opinion, with a consequent change in laws having to do with human relations and rights in a republic such as ours ...." Collier v. Lindley, 203 Cal. 641, 650, 266 Pac. 526, 529 (1928). "To hold that an endeavor to procure, by proper means, a change in a law is, in effect, to attempt to violate that law would discourage improvement in legislation and tend to compel us to continue indefinitely to live under laws designed for an entirely different state of society." Taylor v. Hoag, $273 \mathrm{~Pa}$. 194, 199-200, 116 Atl. 826, 828 (1922). "But even though a constitutional amendment be necessary ... we see no reason for holding that the advocacy of a change of the organic law . . . can be held as against public policy." Garrison v. Little, 75 Ill. App. 402, 413 (1898). Professor Scott states: "In the United States the notion that a trust for a purpose otherwise charitable is not charitable if the accomplishment of its purpose involves a change in existing laws has been pretty thoroughly rejected." 4 Scotr, TRusts $\$ 374.4$, at 2677 (2d ed. 1956). But see Reiling, Federal Taxation: What is a Charitable Organization?, 44 A.B.A.J. 525 (1958).

English authority coincides with the Massachusetts approach. "[A] trust for the attainment of political objects has always been held invalid, not because it is illegal ... but because the Court has no means of judging whether a proposed change in the law will or will not be for a public benefit ...." Bowman v. Secular Soc'y, Ltd., [1917] A.C. 406, 442. See also National Anti-Vivisection Soc'y v. Inland Revenue Comm'rs, [1948] A.C. 31 (1947); Commissioners of Inland Revenue v. Temperance Council, 42 T.L.R. 618, 136 L.T. 27 (1926). It should be noted that American authority does not sustain, as charitable, trusts for political parties. See Boorse Trust, $64 \mathrm{~Pa}$. D. \& C. 447 (Orphans' Ct. 1948); In re Grossman's Estate, 190 Misc. 521, 75 N.Y.S.2d 335 (Surr. Ct. 1947); cf. Liapis Estate, 88 Pa.D. \& C. 303 (Orphan's Ct. 1954). The distinction is not always easily made. See 4 Scotr, Trusts $\$ 374.6$ (2d ed. 1956). 
the responsibility for defining the circumstances under which the limitation was to be applied. Without attempting a detailed analysis of the cases, several generalizations may be made concerning judicial attitudes toward the type and quantum of activity necessary to justify withholding tax privileges. ${ }^{45}$ Judge Hand had made it clear that the fatal flaw in the Slee case was that the League's political agitation was aimed at repeal of all laws which prevented the use of contraceptive devices, rather than being confined to relieving its own medical activities from specific legal obstacles. Under his theory political activities which are ancillary to some primary, nonpolitical objective are permissible. His examples included a society to prevent cruelty to children or animals, a state university, and an association of booklovers or scientists resorting to positive support of law to accomplish their ends. ${ }^{46}$

The 1934 legislation took a slightly different tack by prohibiting only "substantial" participation. The test of substantiality under the statute was not to weigh the amount of political activity standing alone, but rather to balance that activity against the nonpolitical activities of the group. Because the word "substantial" lacks precise content, the courts have been able to invoke it to liberalize the overall restriction. In particular, the taxpayer scored a notable triumph in the 1955 case of Seasongood $v$. Commissioner. ${ }^{47}$ The issue involved the deductibility of contributions to the Hamilton County Good Government League, an association designed to improve local government by group discussions, distribution of literature, investigation of legislation, representations to legislative authorities concerning proposed statutes, and endorsement of candidates. This was enough to convince the Tax Court that the deductions should not be allowed.88 In reversing, the Sixth Circuit limited the scope of tainted political activity to direct appeals to legislative and executive authorities and the support of candidates; general public campaigns for better government constituted permissible

45. For a general review of the relevant cases see Note, Income Tax Disadvantages of Political Activities, 57 Colum. L. REv. 273 (1957); Note, Charitable Trusts for Political Purposes, 37 VA. L. REv. 988 (1951). See also 1956 Wis. L. Rev. 165; 67 Harv. L. REv. 1408 (1954). While the Slee case has had the predominant influence in the field, some courts have seen the problem differently. See, e.g., International Reform Fed'n v. District Unemployment Compensation Bd., 131 F.2d 337 (D.C. Cir.), cert. denied, 317 U.S. 693 (1942); Girard Trust Co. v. Commissioner, 122 F.2d 108 (3d Cir. 1941); Cochran v. Commissioner, 78 F.2d 176 (4th Cir. 1935).

46. Slee v. Commissioner, 42 F.2d 184, 185 (2d Cir. 1930).

47. 227 F.2d 907 (6th Cir. 1955).

48. Murray Seasongood, 22 T.C. 671 (1954), acq., 1954-2 Cum. Bull. 5. 
educational activity. Inasmuch as the League spent less than five per cent of its time and energies on direct action, it followed that this activity was "insubstantial" and that the League qualified as a charity.

To other charities similarly involved in legislative activities, this interpretation seemed to make life immeasurably easier. Direct political action, if for no other reason than that state legislatures convene only periodically, is invariably subordinated to general public education. While the Treasury was not expected to acquiesce in the ruling, organizations looked upon the Seasongood decision as a protective haven. It was widely assumed that in future litigation the Treasury would have to distinguisl or repudiate the distinction drawn there between direct action and public education. Throughout this later period, other groups sought accommodation with the restriction by separating their organizations into two entities, one for political action and the other for research and general education. Under this procedure charitable status was claimed for only the latter branch. It has not always been clear that in the disbursement of the tax-free contributions thus collected the separation of the two entities has been strictly observed.

In 1958 the era of relaxed good feeling seemed to come abruptly to an end. The Treasury was reported to have adopted a more literal, and therefore more aggressive, attitude toward the administration of the statutory prohibitions against political activity. ${ }^{49}$ Approximately fifty organizations lost the deductibility-of-contributions advantage as opposed to less than twenty the year before. ${ }^{50}$ Citizens groups seeking exemptions for the first time met with a hostile reception although they could frequently cite analogous organizations, processed in previous years, which had been favorably treated. Other organizations, such as citizens groups in support of slum clearance and mental health associations, were questioned and sometimes felt compelled to change their charters and programs to meet objections. The Ford Foundation was reported to have been considering a substantial grant to a civic planning organization but channelled the funds to a university instead..$^{51}$ It was believed that this flurry of activity was designed to set the stage for new, more restrictive regulations covering the entire field of political activity. One widely circulated rumor had it that "education," the

49. Grimes, Tax Crackdown, Wall Street Journal, Dec. 9, 1958, p. 1, col. 6.

50. Ibid. The statistics give no breakdown as to whether political activity was the reason for loss of tax advantages. It is, however, a fair assumption that it was significant in many of the cases.

51. Ibid. 
category by which charities customarily excused their political activity, was to be redefined in terms of classrooms, teachers, and pupils.

With the publication of the final regulations in early 1959, all of these fears and fantasies were dispelled. ${ }^{52}$ The regulations proved to be reasonable distillations of existing law without revolutionary innovation. Thus, taxation is dependent on whether the group is operating as an "action" organization. This category includes: (1) an organization which devotes a substantial part of its activities to influencing legislation by contacting, or urging the public to contact, governmental officials, or advocating the adoption or rejection of legislation; (2) an organization which participates in political campaigns or supports candidates; (3) an organization whose primary objectives can only be attained by legislation..$^{\tilde{3}}$ The regulations are instructive on several other related points. Exempt purposes are described by way of the traditional listing of charitable objectives, followed by the statement that such enumeration is not intended to bar other purposes "which may fall within the broad outlines of 'charity' as developed by judicial decisions." 54 Educational purposes are expressly defined to include "instruction of the public on subjects useful to the individual and beneficial to the community." 55 Furthermore, such public instruction may take a point of view so long as the presentation is sufficiently objective to allow members of the public to make an independent judgment. ${ }^{56}$

The impact of these regulations on future developments cannot now be foretold. The retention of broad definitions of charity and education would seem to represent a substantial setback to those who would use the tax exemption as an instrument for the tighter control of philanthropic giving. On the other hand, prohibited political activity includes not only direct contacts with legislatures but also general education urging the public to contact, and in this regard, would appear, to represent a retreat from the extreme liberality of the Seasongood holding. Most significantly, no attempt has been made to give any quantitative content to the key word "substantial." In short, these regulations

52. Treas. Reg. $\$ 1.501$ (c) (3)-1 (1959). For an analysis of these regulations see Sharp, Reflection on the Disallowance of Income Tax Deductions for Lobbying Expenditures, 39 B.U.L. REv. 365, 386-90 (1959). See also Note, Deductibility of Expenses To Influence Legislation, 46 VA. L. REv. 112 (1960).

53. Treas. Reg. $\$ 1.501$ (c) (3)-1 (1959).

54. Treas. Reg. $\S 1.501$ (d) (2) (1959).

55. Treas. Reg. $\$ 1.501$ (d) (3) (i) (b) (1959).

56. Treas. Reg. $\$ 1.501$ (d) (3) (i) (1959). 
are not the final answer. The tests are sufficiently broad to permit either a relaxed or a strict administration depending upon whichever way the Treasury wishes to throw the switch.

This brief history is significant for its failure to reveal any justification for the restriction in its present, all-pervasive form. At no point is the argument advanced that charity and politics are inherently incompatible. The restriction originated as a device to withhold tax subsidies from controversial and selfish purposes. That it presently goes far beyond these narrow limits is due to considerations of administrative convenience rather than substantive policy. The qualification of substantiality is an admission that the restriction overreaches its objectives. It does not, however, provide a basis for selection in terms relevant to the best interests of society.

Those who would leave the law unchanged argue that no affirmative reasons have been given for subsidizing political activities. This is to state the problem unfairly. Tax privileges are granted broadly to an infinite variety of purposes. The burden is upon those who would make political activities in aid of charity an exception to the general rule. Considerations of the practical effects of the restriction demonstrate the difficulties which are involved in sustaining this burden.

\section{The Restriction as Seen From Several Points of View}

\section{A. The Charities Involved}

To the charities who find themselves under the gun the restriction appears indefensible. Charity is not abstract theorizing, removed from the everyday affairs of mankind. Religion, education, and the arts seek in differing ways to condition human conduct to the end that society will be improved. Each has its own agency, be it a congregation, student body, or art patrons, by which its influence is communicated. The charity which is concerned with governmental issues sees itself as not dissimilar. Its niembers are no less dedicated or benevolently motivated in their desire to serve mankind. It finds itself, however, subject to penalty because its message is aimed at the one agency, government in all its forms, which can effect the most immediate solution to society's problems.

A fuller understanding of this viewpoint requires identification of the groups involved. The primary targets of the present law are the citizens groups who support a cause which can only be fully attained 
with the aid of governmental processes. These groups start out with an initial disadvantage which perhaps helps to explain why they are singled out from all other charities for unfavorable tax treatment. They are, to a degree, pressure groups and, as such, are made to suffer in the public eye some of the stigma attached to that term. ${ }^{57}$ But the image of grasping manipulators using devious and secret means to extort selfish advantage is misapplied. The groups under discussion have as a common characteristic some recognized charitable purpose as their end. Only the means used to achieve those ends are being brought into question. On this basis they are immediately distinguishable from the economic pressure group which seeks private gain or preferred treatment, the hate group which seeks antisocial ends, or the political party or group in support of a candidate which seeks political position and power.

Reliable statistics as to numbers and types of groups which might fall into the charitable category are not available. We know that they are numerous and influential at all levels of governmental activity. For purposes of description these groups may be divided into two broad categories. The first includes organizations seelking the solution to a specific social problem: citizens for better public education, the care and treatment of the mentally ill, urban redevelopment and slum clearance, eradication of juvenile delinquency, relief of poverty, homes for the aged, rehabilitation of the alcoholics and addicted-the listing may be continued until it catalogues practically all the ills which beset modern society. Groups in this category have several common characteristics. Their programs usually include a variety of activities which are not dependent upon governmental assistance. For instance, a mental health association will conduct programs of general education aimed at better public understanding of mental illness, volunteer services in mental hospitals, and aid to research, clinics, or other medical services. But while such activities are significant each of these groups has staked out ultimate goals which cannot be attained by private resources alone. If they are to maintain a dynamic program, they must continuously seek enlightened intervention by governmental agencies.

For these groups the political restriction seldom results in loss of charitable status. It is, however, an ever-present and frnstrating factor shaping methods of operation. Boards of directors are aware of the potential penalty for a legislative program which is too substantial, a term which they fear is frequently equated with the success of the

57. See Truman, The Governmental Process 3-13 (1951). 
program. ${ }^{58}$ They find themselves in the anomalous position of speaking with a hesitant, muted voice when every practical consideration requires that their approach be forceful and clear.

Frequently the political limitation as it effects the programs of these welfare groups requires an arbitrary classification. A mental health association is organized to achieve the same ends as the heart, cancer, and polio associations. Treatment and research in the latter fields is located in the hospitals, universities, and drug companies. In contrast, mental illness is almost the exclusive responsibility of state government. If tax differences are to be drawn between these types of health agencies, it must of necessity be on the basis of fortuities quite beyond the control of the parties. A mental health association is only one of many possible examples, and a projection into the future sees this problem becoming increasingly aggravated. Government has preempted much of the welfare field and is assuming an ever-expanding responsibility for education and scientific research. The present law restricts charitable groups fronu making a rational adjustment to this fact of contemporary life. One example spotlights the irony of the situation. Relief of poverty permits soup kitchens, almshouses, and orphan asylums but discourages close cooperation between public and private agencies in working out an enduring solution to the problem.

The second broad category of charities involved is composed of groups which seek strengtheming of governmental processes and institutions as an end in itself. The League of Women Voters and the American Civil Liberties Union are prominent representatives of this category. Other examples at the state and municipal level might include such organizations as citizens for better courts, constitutional revision, reapportionment, reform of county government, charter revision, and so forth. While their motives are dedicated to the improvement of man's position in society and while they conduct independent programs of research and education, their ultimate goals have almost umformly been characterized as political, and tax privileges have accordingly been withheld. ${ }^{59}$

58. Success of the operation is not part of the legal test of substantiality. It is, however, an important practical consideration. The more influential a group becomes the more attention it draws to its activities, and the greater becomes the likelihood of its being challenged by the Service.

59. However, the League of Women Voters has won some victories. See Liberty Nat. Bank \& Trust Co. v. United States, 122 F. Supp. 759, 766 (W.D. Ky. 1954):

In urging the citizenship within the area of its influence to quatify as voters 
The effect need not be fatal to the organization's existence. Unlike many of the welfare groups which require tax-free contributions to support high cost programs of varied services, the reform groups depend for much of their work upon the personal participation of their members. The pinch is nonetheless there. Experience shows that sizeable donations of a type necessary to sustain campaigns of public education are not forthcoming unless they are deductible. In addition, charitable status has come to symbolize stability and respectability. The defrocked organization frequently finds itself at a disadvantage in recruiting menbers and in obtaining the cooperation of other community agencies, including the press, radio, and television.

\section{B. A Democratic Society}

Because the ultimate aims of the above groups are not being put to challenge, it follows that there is something inherently improper in the use of political means. To test the validity of this proposition requires a brief inquiry into the role which these groups play as a part of a functioning democracy.

Experts in the field of political institutions recognize that groups, using the term in its most comprehensive sense to include business, labor, trade, veterans, professional, and farm associations, are an important fact to an understanding of governmental operations. ${ }^{60}$ They arise as a response to the individual's conviction that alone he is powerless to shape public policy, and that only in association with persons who share his viewpoint does he assume sigmificant leverage. Assessments as to whether this type of pluralistic distribution of power is beneficial or inimical to the best interests of the community are too numerous to be more than suggested here. ${ }^{61}$

and to be informed upon the issues settled by exercise of the suffrage of the electorate, the League has rendered invaluable services in the fight against carelessness and indifference in public affairs. If upon sporadic occasions the zeal of its members has invaded the prohibited area of attempting to influence legislation, this becomes of little consequence viewed against the background of the whole of their efforts in behalf of better government.

See also Luther Ely Smith, 3 T.C. 696 (1944). In spite of these rulings, the League in most sections of the country is not exempt, and members are advised that dues and other contributions are not deductible.

60. The literature on the subject is voluminous. Two of the outstanding works are Trumlan, The Governmental Process (1951) and Key, Politics, Parties, and Pressure Groups (4th ed. 1958).

61. See Truman and KeY, op. cit. supra note 60 , and references cited therein. Implications of the problem go beyond the single question of service or disservice to the 
Commentators have emphasized two serious deficiencies in contemporary democracy: the inability of decision-makers to keep abreast of the varied and complex issues coming before them, and, as a product of the system of geographical representation, the tendency of legislators to respond to local rather than national interests. It is argued that the existence of groups representating a multiplicity of interests works to correct these defects by providing both a flow of information and representation to interests which transcend geographical boundaries. ${ }^{62}$ There is, on the other hand, a strong current of American thought which views interest groups as a corrupting influence on the democratic process. The democratic ideal assumes a legislator with all the facts making an independent judgment. Groups, it is argued, supply distorted information and frequently resort to coercive techniques, such as threats of reprisals and bribes in the form of campaign contributions, which make independent judgment impossible. ${ }^{63}$

community. For instance, the author of a recent analysis of municipal government in Philadelphia details the significant contributions made by reform and service groups. He concludes, however, that the existence of such groups is a mixed blessing. His point may be summed up in the following observation:

The flourishing American institution of service clubs is a perfect device for political behavior that is at the same time outside of real politics. The service clubs perform the subsidiary functions of managing charity, providing an outlet for gregarious impulses, and giving their members a chance to make valuable business contacts; but anyone who has observed their highly organized and extreniely active hierarchies of administration, or participated in the parliamentary debates of their conventions and local meetings, must be struck by the fact that they are primarily instruments to enable their members to enjoy the sensations of government while incurring few of its responsibilities. The same can probably be said for many veteran and fraternal organizations and for many organizations of women in the United States. A great many members of the service clubs before whom I have talked agree that the tragedy of the service clubs is that they liarness enormous political energies to the necessary but nonetheless secondary tasks of charity and community recreation, while leaving the primary work of government to the frequently ill-equipped, ill-directed, and illmannered party machines. Reichley, The ART of GovernMeNT 125 (1959).

62. This generalization is too simple and overdrawn to represent the views of any one person. For an incisive evaluation of the place of groups in American democracy see Truman, op. cit. supra note 60,501-35. Of the many statements as to the need for decision-makers to be kept informed one by Walter Lippmann is representative. "I argue that representative government ... cannot be worked successfully, no matter what the basis of election, unless there is an independent, expert organization for making the unseen facts intelligible to those who have to make the decisions." LIPPMANN, Public OpINIon 31 (1922).

63. This attitude has been strongly held throughout American history. See Truman, op. cit. supra note $60,3-13$. It is periodically recharged by such episodes as the offer of a $\$ 2,500$ campaigu contribution to Senator Francis Case of South Dakota in 1956 fot an affirmative vote on the natural gas bill which was then before the Senate. President 
When the inquiry narrows to those groups which are organized for charitable objectives, the specter of the corrupt lobbyist and unscrupulous tactics is removed. Charity requires ethical standards in the pursuit of selfless ends. For those who take advocacy beyond the bounds of propriety, there is an immediate sanction in the form of the withdrawal of charitable privileges. The problem at this point becomes relatively simple if we further limit our focus to those charitable groups who seek objectives about which there is no taint of controversy. Here the use of political means serves both charitable and democratic goals. It broadens the democratic base by recruiting, in the formulation of policy, the participation of persons who otherwise would remain passive; it provides a forum for an exchange of ideas and the evolution of responsible policies; and it keeps governmental authorities alert to new and creative approaches to age-old problems. ${ }^{64}$

Reservations arise when we postulate purposes which, while charitable, evoke sharply divergent public reactions. Birth control, court reorganization, and fluoridation of drinking water miglit serve as examples. The

Eisenhower vetoed the bill because of such "arrogant" tactics. 102 Cong. REc. 2793, 2897-98 (1956). The story is well told in Peters, Political Campaign Financing: Tax Incentives for Small Contributors, 18 LA. L. Rev. 414 (1958). The force of this attitude is apparent in such attempts at regulating lobbying as the Federal Regulation of Lobbying Act, 2 U.S.C. $\$ \$ 261-70$ (1958). See Note, Improving the Legislative Process: Federal Regulation of Lobbying, 56 YaLE L.J. 304 (1947).

64. A recent survey of charitable trusts in England has described the contributions of voluntary groups in the following terms:

When we turn from voluntary service as such to consider the place of voluntary organizations in the modern social structure more complex considerations arise. The advantage of voluntary effort over state activity lies in its greater flexibility; its ability to set new standards or to undertake new work of its own volition, and without seeking fresh statutory powers; its ability to pioneer; to make additional or more special provision for people suffering from certain types of disadvantages or disabilities; or for young people of exceptional promise; to work outwards from the individual in need of help to the services he needs rather than by the reverse process of discovering the individual in providing a service (we have in mind particularly the case work agencies); to attract to it men and women with a high sense of dedication ready and willing to give themselves to taxing and specially difficult work. We will not enlarge on these virtues, which few would deny. Some of the most valuable activities of voluntary societies consist, however, in the fact that they are able to stand aside from and criticise state action, or inaction, in the interests of the inarticulate man-in-the-street. This may take the form of helping individuals to know and obtain their rights. It also consists in a more general activity of collecting data about some point where the shoe seems to pinch or a need remains unmet. The general machinery of democratic agitation, deputations, letters to the Press, questions in the House, conferences and the rest of it, may then be put into operation in order to convince a wider public that action is necessary. Committee on Law and Practice, Report Relating to Charitable Trusts, CMID. No. 8710, 13 (1952) (Nathan Report). 
need for information and ideas is not diminished because the issue is controversial. But in the interests of a proper functioning of the democratic process, it is necessary that the flow of information and ideas either be broadly representative of the entire commumity's attitude or, in the alternative, that there be equal opportunity for presentation of contrary viewpoints.

It is obvious that tax deductions are not equally available to every citizen. Statistics indicate that approximately twenty-five per cent of the taxpayers itemize their deductions. ${ }^{65}$ Only within this group is a tax incentive for charitable giving meaningful. And with the estate and gift taxes, which are applicable to a very small segment of the population, the distortion is even more pronounced. ${ }^{60}$ In addition, as a consequence of the graduated rate structure, the high bracket taxpayer is able to deduct a much greater proportion of his contributions than the less well endowed citizen. ${ }^{07}$ A system weighed so heavily in favor of the wealthy would seem to be productive of philosophies associated only with the well-to-do.

There can be little doubt that considerations of this kind have had an important influence on the evolution of the present law. The authors of the 1934 legislation were primarily concerned about the enterprise which, under the guise of charity, was designed to promote private economic interests. It is, however, quite another thing to conclude, as the authors of the legislation in effect did, that the potential for selfish enterprises sweeps every other consideration before it. For the majority of welfare and governmental reform issues, economic interests do not dictate a "party line." Such traditional labels as "liberal" and "conservative" do not help in explaining public concern for the poor, the sick, or the malfunctioning governmental institution, nor do

65. Internal Revenue Service, Statistics of Income for 1953 pt. 1, at 6 (1957).

66. With the various exemptions and the marital deduction privileges only a very small precentage of persons is effected by these taxes. See BitTKER, Federat INCOME Estate aNd Gift Taxation 807-22 (2d ed. 1958); Warren \& Surrey, Federal Estate and Gret Taxation 10-13 (1956).

67. "A low bracket taxpayer who donates a deductible $\$ 100$ is contributing $\$ 80$ of his own money and $\$ 20$ of Uncle Sam's; these figures reverse in the high income brackets." Peters, Political Campaign Financing: Tax Incentives for Small Contributors, 18 LA. L. Rev. 414, 428 (1958). This disparity in opportunity has been noted, for instance, by Judge William Clark, dissenting in Girard Trust Co. v. Commissioner, 122 F.2d 108 (3d Cir. 1941). "Undoubtedly, however, there is a faint odor of harm in the use of money to represent only one side on any proposition. To paraphrase, it may place the Lord on the side of the heaviest money-bags." Id. at 114. 
they provide a basis for prediction as to attitudes and policies which a civic organization will sponsor.

Corrective forces are at work in every organization tending to ameliorate the highly individualistic prejudices of particular members. In order to maximize its influence, a group will consciously strive to broaden its membership base. Policy and program are shaped in a setting which, although in miniature, is not dissimilar from the legislature. A range of differing points of view must be accommodated if the group is to keep its cohesion. "Thus the leaders of the ParentTeacher Association must take some account of the fact that their proposals must be acceptable to members who also belong to the local taxpayers' league, to the local chamber of commerce, and to the Catholic Church." 68

Democratic principles further require that tax privileges do not operate to favor one side in a controversy. It is a weakness of the present law that such discrimination does occur. A large charity may engage in political activity so long as that activity is insubstantial in comparison with the charity's other activities. In Connecticut the Catholic Church is largely credited with blocking any modification of the local law making the use of any contraceptive device subject to criminal penalties. ${ }^{69}$ While in an absolute sense this activity is substantial, it is obviously but an insignificant part of the Church's overall activities and in no way threatens its tax status. A birth control league sounding an opposition voice, however, will receive no such advantages from the Treasury.

A relaxation of existing restraints could effect an adjustment of such discriminations. It does not, however, follow that a millennium will result whereby all viewpoints are heard in equal debate with government free to select the soundest course. The problem is blown up beyond its practical significance. Welfare and reform issues divide citizens

68. Truman, op. cit. supra note 60 , at 509. See also KEY, op. cit. supra note 60 , at $166-67$.

69. Conn. Gen. Stat. Rev. $\$ 53-32$ (1958). By using this one example the author does not intend to suggest that the Catholic Church is the only religious body taking political positions. On the role of organized religion in politics see KEY, op. cit. supra note 60, at 130-34. See generally Prefrer, Church, State, and Freedom (1953). On the general problem of "tax equilibrium" (equality of opportunity in receiving tax deductions) see the incisive analysis of the related area of business expense deductions for lobbying expenditures appearing in Sharp, Reflection on the Disallowance of Income Tax Deductions for Lobbying Expenditures, 39 B.U.L. Rev. 365, 376-80 (1959). See also Note, Deductibility of Expenses to Influence Legislation, 46 VA. L. Rev. 112 (1960). 
into those who favor innovation and those who oppose it. The burden is invariably upon the former, and rare indeed is the situation in which the forces of the status quo are under-represented.

\section{The Treasury ${ }^{70}$}

The factors which have shaped the political activities restriction come into focus when the problem is viewed from the perspective of the Treasury. To the collector of the taxes and the guardian of the tax law, political theorizing is irrelevant. It is concerned on two counts with tax support of controversial issues. First, it does not want the unenviable task of selecting those political purposes which are compatible with charitable principles and rejecting those which are not. Within the last decade two congressional committees have demonstrated particular interest in the political outlook of tax-fee charities. ${ }^{71}$ Understandably, there is no desire to provoke the sleeping lion once again. Secondly, the Treasury must replace those tax losses resulting from deductions out of other taxes without destroying public confidence in the integrity of the system. It is obviously difficult to justify a tax subsidy for a political purpose with which a considerable segment of the population is out of sympathy.

These considerations cannot be dismissed with the accusation that the Treasury is trying to sweep a difficult problem under the carpet. A few of the possibilities include: birth control-an issue so explosive that it may well decide the outcome of a presidential election; fluoridation of water-an issue which has torn a number of communities asunder, each competing group claiming to have the true scientific, ethical, and religious word; segregated schools-an issue on which approximately one-third of the nation is already in open revolt against federal authority. Moreover, the elements of controversy are not always apparent from the statement of purpose. If good government leagues were

70. The author, of course, has no authority to speak for the Treasury. The assumed difficulties of administration have always been of major concern. See, for instance, the remarks of Senator La Follette at the time of the enactment of the 1934 legislation. 78 Cong. Rec. 5959 (1934).

71. Special Comm. To Investigate Tax-Exempt Foundations and Comparable Organizations, Report on Tax-Exempt Foundations and Comparable Organizations, H.R. Rep. No. 2681, 83d Cong., 2d Sess. (1954) (Reece Committee); Select Comm. To Investigate Foundations, Final Report, H.R. Rep. No. 2514, 82d Cong., 2d Sess. (1953) (Cox Committee). For contrasting studies of the work of these committees compare Macdonald, The Ford Foundation 19-35 (1956), witb Wormser, Foundations: Their Power AND INFLUENCE (1958). 
to become charitable, what of such a league if it is a front for known communists? What if it is organized by the loyal disciples of such anathemas to the liberal or conservative segments of American society as Senator McCarthy on the one hand and Walter Reuther on the other? ${ }^{72}$ A recent Supreme Court decision held, in another context, that a blanket restriction on deductions for political activities does not present the constitutional issue of a denial of free speech. ${ }^{73}$ If, however, such deductions were generally allowed, an administrative process which appears to discriminate on the basis of the degree of controversy involved might place the constitutional issue in a different light. ${ }^{74}$

The Treasury originated the restriction against political activities, and its view has prevailed without serious challenge. This fact explains why the law is written in blacks and whites and why the one exception to it is defined in terms of amount, rather than kinds of activity.

\section{Is a Change in the Law Possible?}

It has been apparent that this writer favors relaxation of the restriction. Solicitude for the Treasury's position cannot alter the fact that the existing law arbitrarily discriminates against many worthwhile enterprises only because of the alleged administrative difficulties in separating the good from the bad. Throughout the law lines must be drawn. If decision-makers give way to the fear of what-might-be, the law becomes paralyzed and ineffective as an instrument of social control. Or, to echo an English judge: “[I]t is not a valid objection to a legal doctrine that it will not be always easy to know whether the doctrine

72. It might be argued today that the test of substantiality as used in the cases becomes increasingly strict as the political objective in issue becomes more controversial. Certainly purposes which do not coincide with widely prevailing attitudes are given short shrift. See Sharpe's Estate v. Commissioner, 148 F.2d 75 (3d Cir. 1945); Marshall v. Commissioner, 147 F.2d 75 (2d Cir. 1945); Anita McCormick Blaine, 22 T.C. 1195 (1954). If the present restrictions were to be removed the purpose would still have to qualify as charitable. This would exclude support of parties and candidates and purposes which require allegiance to a foreign power or antisocial atritudes such as anti-Semitism and the like. Within these limits varying degrees of liberalism or conservatism would be irrelevant.

73. Cammarano v. Umited States, 358 U.S. 498 (1959); see Sunderland, Taxation of Free Speech, 26 U. Cri. L. Rev. 109 (1958) (pre-Cammarano); Note, Deductibility of Expenses To Influence Legislation, 46 VA. L. Rev. 112 (1960) (post-Cammarano).

74. "It cannot be gainsaid that a discriminatory denial of a tax exemption for engaging in speech is a limitation on free speech." Speiser v. Randall, 357 U.S. 513, 5 I8 (1957). 
is to be applied in a particular case. The law has to face such embarrassments." 75

Even if the present law were to be totally abrogated, tax privileges would only be granted to activities which are charitable, as opposed to those which are private, selfish, or against public policy. And sound policy suggests that the charitable category should continue to exclude partisan support of parties and candidates. ${ }^{76}$ The objections to liberalizing the law become less persuasive when viewed in light of the fact that the federal and state taxing authorities are already making just these kinds of decisions in cases which do not present issues of political activity. Tax privileges are allowed to schools which discriminate against Negroes, ${ }^{77}$ to competing religious sects, ${ }^{78}$ to birth control clinics, ${ }^{79}$ to privately endowed dental schools which undoubtedly include, among other research projects, studies of water fluoridation, and, even occasionally, to a controversial reform movement. ${ }^{80}$ Obviously these activities do not

75. Dashwood v. Maginac, [1891] 3 Ch. 306, 364 (C.A.) (Bowen, L.J.). For a collection of similar statements see Williams, Language and the Law-II, 61 L.Q. Rev. $179,184-85$ (1945).

76. In this manner private and tax law definitions are kept in harmony. See note 44 supra. This is not to say that a persuasive argument in favor of tax incentives for political contributions cannot be made without justifying such privileges as charitable. See Peters, Political Campaign Financing: Tax Incentives for Small Contributors, 18 LA. L. Rev. 414 (1958).

77. In the recently concluded litigation concerning Girard College, the extensive tax exemptions (primarily local property taxes) accorded the college were argued as a basis for prohibited state action under the fourteenth amendment. This specific point was largely ignored in the decisions. See Girard Will Case, $386 \mathrm{~Pa} .548,127$ A.2d 287 (1956) (discrimination under a will not actionable even though an agency of the City of Philadelphia was acting as trustee), rev'd sub nom. Pennsylvania v. Board of Directors of City Trusts, 353 U.S. 230 (1957) (city's participation as trustee prohibited state action); Girard College Trusteeship, $391 \mathrm{~Pa} .434,138$ A.2d 844 (1958) (city board reconstituted as private agency, discrimination under will continued), cert. denied, 357 U.S. 570 (1958). For a discussion of tax exemptions as a basis of state action see the opinions of Judge Musmanno, dissenting to the several decisions of the Pennsylvania Supreme Court in Girard, supra. On state discrimination and tax exemptions see also Dorsey v. Stuyvesant Town Corp., 299 N.Y. 512, 87 N.E.2d 541 (1949), cert. denied, 339 U.S. 981 (1950). Direct subsidies to private discrimination are, however, prohibited state action. See Kerr v. Enoch Pratt Free Library, 149 F.2d 212 (4th Cir. 1945), cert. denied, 326 U.S. 721 (1945).

78. See 4 Scotr, Trusts $\$ 371$ (2d. ed. 1956) and the cases collected therein. See also note 9 supra.

79. Faulkner v. Commissioner, 112 F.2d 987 (1st Cir. 1940); of. Slee v. Commissioner, 42 F.2d 184 (2d Cir. 1930). The Albert and Mary Lasker Foundation for medical research, including planned parenthood, is listed as qualified to receive deductible contributions. Internat. Revenue Service, Cumulative List of Organizations 146 (1957).

80. The Robert Schalkenbach Foundation, Inc., of New York City, organized "to 
have the approval of every section of society. The dissenters are taxed, nevertheless, to cover the loss of revenue occasioned by these subsidies. The problems raised by the controversial purpose are substantial, but they are general to the field of deductions, not specific to one small corner of it. ${ }^{81}$

Free speech objections to the process of selection are not wellfounded. Charitable status is a rational classification for permitting or denying tax privileges. ${ }^{82}$ More serious constitutional questions, those presented by the discriminatory trust under the equal protection clause of the fourteenth amendment ${ }^{83}$ and by the religious trust under the separation principle of the first amendment, ${ }^{84}$ have been warily avoided by the Supreme Court. It seems highly unlikely that the Court at some future time will be looking to compound these problems.

But ultimately any proposals for amending the law must take into account what, as a practical matter, can be obtained. As the Supreme Court recently has indicated, there is no constitutional basis on which to invalidate the political activities section of the statute. ${ }^{85}$ The case upheld the Treasury regulation which provides that no business deduction shall be allowed for sums of money expended to defeat legislation, even though that legislation would seriously affect the taxpayer's busi-

keep before the public the ideas of Henry George," is listed as a charitable organization entitled to receive tax deductible contributions. Id. at 226; of. Sharpe's Estate v. Commissioner, 148 F.2d 179 (3d Cir. 1945).

81. Althougli there is presently no discernible agitation for reforn1, it seems inevitable that at some future time there will be eitler a legislative or judicial reappraisal of tax privileges for organizations which actively discriminate against certain segments of society. There is also the problem of tax loss through deductions and exemptions. See note 93 infra. There have been a few voices over the years suggesting that government may be able to do the job better. "But it has been obvious, at least since the days of the Tudors, that, from the fiscal point of view, taxation is a more satisfactory expedient than exhortations to private beneficence. It is also certain that it is likely to be a more efficient method of reducing inequality than the encouragement of philanthropic bequests." Wedgwood, The Economics of INHeritance 91 (1929).

82. This assumption underlies the whole structure of deductions and exemptions and is not now open to question. See Trinidad v. Sagrada Orden De Predicadores, 263 U.S. 578 (1924) (1913 federal income tax); University v. People, 99 U.S. 309 (1878) (state taxes).

83. For a discussion of this issue see Clark, Charitable Trusts, the Fourteenth Amendment and the Will of Stephen Girard, 66 YaLE L.J. 979, 1001 (1957).

84. See Pfeffer, Church, State, and Freedom 183-91 (1953); Katz, Freedom of Religion and State Neutrality, 20 U. CHI. L. Rev. 426, 432-33 (1953); Paulsen, Preferment of Religious Institutions in Tax and Labor Legislation, 14 Law \& Contemp. Prob. 144, 148-52 (1949).

85. See Cammarano v. United States, 358 U.S. 498, 512-13 (1959). 
ness. ${ }^{86}$ As a part of its holding, the Court, quoting with approval from the Slee case, ${ }^{87}$ cited the restriction upon charities as representing a "sharply defined policy" which the Treasury could legitimately carry over into the field of business deductions. ${ }^{88}$ Nor is there any likelihood that Congress, particularly after a record of consistent success before the courts, will be in a mood to reexamine the question. ${ }^{89}$

With judicial and legislative reform ruled out, the only avenue open is a general plea to the Treasury for a flexible administration of existing law. The key remains the word "substantial," a term which does not define its own limits. In interpreting this word it would be consistent with the history and policy of the statute to strike aggressively at political activities which are selfishly conceived for personal advantage, but to maintain a strong presumption in favor of the activities of genuine charities. The Seasongood ${ }^{90}$ ruling suggests a workable approach to the problem, with particular reference to three points contained therein. First, the case inferentially denies the validity of the distinction between organizations which seek legislative ends as a primary goal and those which engage in political activity as a secondary part of their programs. Second, it confines the scope of prohibited activity to direct representations to governmental officials, an interpretation which finds further support in the Supreme Court's ruling upholding the Federal Regulation of Lobbying Act as thus limited.91 And third, as a corollary of the other two, it defines permissible education broadly to include the general education of the public to the need for governmental reform.

The section of the new regulations on education gives reason to hope that progress can be made in this direction and that the unnecessary rigidities of the previous law, which are continued in the definition of an action group, can be deemphasized.92 The Treasury might need

86. Treas. Reg. $\S 1.162-15$ (1958), as amended, T.D. 6435 , 1960 Inr. Rev. BuLt. No. 4 , at 7 .

87. See notes 32-37 supra and accompanying text.

88. Cammarano v. United States, 358 U.S. 498, 512 (1959).

89. The trend in Congress has not been to encourage greater expenditures of money for political activities. Althougl the subject matter and policy issues involved are clearly distinguishable from the present question, the vote of the Senate on January 25, 1960, tightening up the Corrupt Practices Act of 1925, is perhaps indicative of the temper of the times. S. 2436, 86th Cong., 2d Sess., 106 Cong. Rec. 1067 (daily ed. Jan. 25, 1960); N.Y. Times, Jan. 26, 1960, p. 1, col. 3.

90. Seasongood v. Commissioner, 227 F.2d 907 (6th Cir. 1955).

91. United States v. Harriss, 347 U.S. 612, 620-21 (1954).

92. Treas Reg. $\$ 1.501$ (c) (3)-1(c) (3) (1959) (definition of an "action organization"); Treas. Reg. $\$ 1.501$ (c) (3)-1(d) (3) (1959) (definition of education). 
additional controls for protection against frequent demands brought by insubstantial, temporary action committees. And it is conceivable that standards might be developed calling for a period of probation, a minimum number of adherents, and a record of past activity, which demonstrates that the viewpoint of the association has been fairly represented to the public.

\section{ConCLUSION}

The story of the restriction on political activities is instructive on the feasibility of applying legal controls in the field of philanthropy. The stakes are substantial. On the one hand, society has a vital interest in protecting the tax base from further erosion through deductions. ${ }^{93}$ While a reversal of the law on political activities would result in an insignificant drain on federal revenues, it might, however, have repercussions in other areas of tax law. Much that has been argued here can be applied in favor of the deductibility of lobbying costs as business expenses, ${ }^{94}$ or of a credit for contributions to political parties and candidates.95 On the other hand, there is society's interest in preserving charity as a dynamic institution. There are already potent forces tending to make charity overly timid. ${ }^{96}$ If charity is to meet the challenge of the future, it must be prepared to strike out boldly, to experiment and lead in ways which are not open to government. ${ }^{97}$

93. See Pechman, Erosion of the Individual Income Tax, 10 NaT'L TAx J. 1 (1957). The author estimates that individuals deducted 4.4 billion dollars for charitable contributions against their 1956 income taxes. Very few studies have been made of the total impact of charitable giving on state and federal revenues. Isolated references include: Adler, Tax Exemptions on Real Estate 91-99 (1922); Stimson, The Exemption of Property from Taxation in the United States, 18 MiNN. L. Rev. 411 (1934).

94. See Sharp, Reflection on the Disallowance of Income Tax Deductions for Lobbying Expenditures, 39 B.U.L. Rev, 365 (1959); Spiegel, Deductibility of Lobbying, Initiative and Referendum Expenses: A Problem for Congressional Consideration, 45 CauIF. L. Rev. 1 (1957).

95. See Peters, Political Campaign Financing: Tax Incentives for Small Contributors, 18 LA. L. REv. 414 (1958).

96. See Macdonald, The Ford Foundation 165-74 (1956); Embree, Timid Billions, Harper's, March, 1949, p. 28.

97. The justification of philanthropy as venture capital, free to move into areas where government fears to tread, has been expressed many times. The statement of Henry Ford II to the Cox Committee is representative. "We believe that foundations, by and large, provide what some one has called the venture capital of philanthropy .... To do so they must from time to time pioneer, underwrite experiments, and encourage programs and projects that might otherwise never have a chance." Hearings Before the Select House Conmittee To Investigate Foundations and Otber Organizations, 82d Cong., 2d Sess. 220 (1952). 
Controls are an obstacle to this kind of growth. So it is that the restriction on political activities illustrates all the difficulties of attempting to fashion one rule to cover an infinite variety of dissimilar situations. It deprives society of aid and leadership in the field of government; its administration is inevitably arbitrary and discriminatory; and, as the trend toward the welfare state continues apace, it presages a steady shrinking of areas open to charity.

Is it not probable that the picture of people acting in irrational and antisocial ways has been greatly overdrawn? Charity has prospered free of legal controls in the past. Its stability has been maintained because men of goodwill, without thought of personal advantage, have sought to benefit society in ways that society may approve. The Treasury should take cognizance of this tradition by giving a flexible interpretation to the present law. 